\title{
Effects of sea level rise on growth of Spartina anglica and oxygen dynamics in rhizosphere and salt marsh sediments
}

\author{
Marianne Holmer*, Britta Gribsholt, Erik Kristensen \\ Institute of Biology, SDU-Odense University, Campusvej 55, 5230 Odense M, Denmark
}

\begin{abstract}
The effect of sea level rise on the growth of Spartina anglica seedlings and on key sediment biogeochemical variables (oxygen concentrations and sulfur cycling) was studied for 4 mo in a laboratory experiment. S. anglica, grown under drained and waterlogged conditions, showed no significant differences in leaf elongation and above-ground biomass between treatments. Sulfate reduction rates were not significantly different between treatments $\left(4.1\right.$ and $5.3 \mathrm{mmol} \mathrm{m}^{-2} \mathrm{~d}^{-1}$, respectively), and although pools of reduced sulfides were high (12.1 to $\left.14.9 \mathrm{~mol} \mathrm{~S} \mathrm{~m}^{-2}\right)$, no dissolved sulfides were detected in the sediments. Measurements of oxygen concentrations in rhizosphere sediment done with microelectrodes revealed a distinct oxic microzone of up to $2.5 \mathrm{~mm}$ around the roots of $S$. anglica. The oxic microzone comprised 30 to $60 \%$ of the $S$. anglica rhizosphere sediment, suggesting that the root-mediated oxygen supply to the rhizosphere has profound effects on the microbial processes in the sediments. The sulfate reduction was probably hampered due to the root-mediated loss of oxygen from the plants. There was no difference in oxygen dynamics in the rhizosphere between treatments, indicating that $S$. anglica is efficient in oxidizing the sediments also under waterlogged conditions. The root-mediated loss of oxygen from $S$. anglica counteracts the expected changes in sediment conditions as a consequence of sea level rise, e.g. accumulation of phytotoxic compounds such as sulfides. The results suggest that possible negative impacts of sea level rise are more likely to be found for plants with less developed root systems.
\end{abstract}

KEY WORDS: Spartina anglica $\cdot$ Salt marsh sediment $\cdot$ Sulfur cycling $\cdot$ Oxygen dynamics $\cdot$ Plantsediment interactions

\section{INTRODUCTION}

Sea level rise as a result of global climatic change poses a threat to salt marshes due to their location in the shallow transition zone between land and ocean (Boorman 1999). Salt marshes are relatively vulnerable to damage by wave actions, and changes in sea level may increase the erosive forces on the seaward edge (Adam 1990). Salt marsh vegetation structure and composition is also controlled by the sea level, and the establishment of vegetation on mud flats, the first initial step in salt marsh formation, only occurs when the mud flats have accreted to a sufficiently high level. Pioneer species start colonizing when mud flats are

\footnotetext{
*E-mail: holmer@biology.sdu.dk
}

covered by water for less than $6 \mathrm{~h} \mathrm{~d}^{-1}$. The pioneer zone extends up to the mean level of high water with a relatively open vegetation dominated either by annual species such as Salicornia and Suaeda or by the perennial grass Spartina sp. As the level of the marsh surface rises the duration of inundation decreases and the pioneer species are replaced by a wider range of species, and the middle and high marsh become progressively more floristically diverse (Adam 1990).

The ability of pioneer species to colonize the low marsh and mudflat is associated with their capacity to maintain the roots oxic during submergence in contrast to less flood tolerant species that lack this feature. Flood tolerant species have a large internal lacunae system, which allows transport of oxygen from shoots to roots (Arenovski \& Howes 1992, Naidoo et al. 1992, 
Howes \& Teal 1994). The internal oxygen concentration of intertidal plants has been found to decline during submergence and recover during emergence. Oxygen is only depleted in the roots during extreme conditions, e.g. at high temperatures in darkness during extended periods of submergence (Gleason \& Zieman 1981). Enhanced flooding with a longer duration of inundation has, however, been shown to hamper the growth of pioneer species such as Spartina (Pezeshki 1997). The observed reduced rates of photosynthesis and reduced growth of roots are probably due to a reduced supply of oxygen to the roots (Mendelssohn \& Patrick 1981, Pezeshki \& DeLaune 1990, 1996), suggesting that Spartina may be negatively influenced by a rise in sea level.

Salt marsh sediments are multifaceted, being influenced by plant activity, microbial decay of organic matter and tidal flooding. The sediments are usually organic-rich due to the high plant biomass and sedimentation of organic matter from external sources or from benthic microalgae (Boorman 1999). At the same time, salt marsh sediments are characterized as reducing environments with high concentrations of sulfides originating from the high rates of anaerobic sulfate reduction (Howarth \& Teal 1979). It is expected that a rise in sea level will accentuate the reducing conditions in the sediments due to the lower oxygen availability associated with increased water level and inundation frequency. This may affect plant roots, e.g. if free sulfide accumulates in the already less oxidized root zone. The evidence for toxicity of sulfides to salt marsh plants is not fully conclusive (Mendelsohn \& McKee 1988, Koch et al. 1990), but sulfide is a known inactivator of metallo-enzymes (e.g. in photosystem II). In addition, stunted roots and blockage of vascular and gas-pathways have been found in Phragmites australis (Armstrong et al. 1996, Fürtig et al. 1996). A lowered root-mediated supply of oxygen into the rhizosphere to compensate for increased sulfide concentrations may worsen the situation.

The aim of this study is to explore the effect of sea level rise on seedlings of the pioneer species Spartina anglica with focus on the interactions between plants and sediment biogeochemistry. Changes in sediment sulfide production and pools of sulfides were examined together with the ability of seedlings grown in the laboratory under drained and waterlogged conditions to oxidize the sediment through root-mediated supply of oxygen into the rhizosphere.

\section{MATERIALS AND METHODS}

Field sampling and establishment of microcosms. Seedlings of Spartina anglica and sediment were collected in Ho Bugt on the southwest coast of Jutland,
Denmark, in March 1999. Seedlings were dug up in blocks of sediment and transported to the laboratory, where they were carefully rinsed and separated into individual plants. Sediment without live vegetation was collected on the seaward edge of the salt marsh. Dead roots and plant detritus were removed manually. The sediment was allowed to restore for $2 \mathrm{~d}$ before further processing. Subsamples of the sediment were taken for initial measurements of sediment characteristics and total pools of reduced sulfides (see below). The seedlings were planted in the sediment, and each seedling with sediment was transferred into a black net stocking and placed in a plexiglass core (i.d. = $8 \mathrm{~cm}$, length $=12 \mathrm{~cm}$ ) with a bottom stopper. The sediment surface was positioned $0.5 \mathrm{~cm}$ from the top of the core and 5 replicate plant microcosms were established for drained and waterlogged treatments in duplicate. The water level of the drained microcosms was lowered to $5 \mathrm{~cm}$ sediment depth through holes in the side of the tube, whereas only the top $\mathrm{cm}$ of the waterlogged sediments was drained. The microcosms were placed in an aquarium (40 l) and kept at in situ salinity (15 PSU) and a temperature of $15^{\circ} \mathrm{C}$ in a $12: 12 \mathrm{~h}$ light:dark cycle. The light intensity was approximately $1000 \mu \mathrm{mol}$ photons $\mathrm{m}^{-2} \mathrm{~s}^{-1}$, which ensures light saturated growth. The microcosms were submerged for $1 \mathrm{~h}$ during each light and dark period to simulate conditions in the field. The water was recycled between the aquaria and a holding tank (50 l), and was renewed every $2 \mathrm{wk}$ during the growth period of $4 \mathrm{mo}$.

Oxygen and sulfide microprofiles in rhizosphere sediment. The oxygen distribution was measured in the rhizosphere when the plants had grown for 4 mo. Commercially available Clark-type microelectrodes (Unisense, Aarhus, Denmark) with a tip diameter $<10 \mu \mathrm{m}$, a $90 \%$ response $<1 \mathrm{~s}$ and a stirring sensitivity of $<1 \%$ were used. The electrode signal was logged on a datalogger (PicoLog: Pico Technology, St Neots, UK) connected to a picoammeter (Unisense). The microelectrode was mounted on a micromanipulator, which allowed a spatial resolution of $10 \mu \mathrm{m}$. The oxygen penetration depth was measured in light and darkness, as well as under emerged and submerged conditions in both drained and waterlogged microcosms.

Mapping of free oxygen in the rhizosphere was done by approaching roots by chance from the sediment surface. It was not possible to visually inspect the root distribution in the microcosms, but tests with visual identification of the root surface through a dissection microscope have shown that oxygen rapidly reaches a constant concentration (20 to $30 \mu \mathrm{m}$ ) after the electrode penetrates a root. The position of root surfaces in the microcosms was thus set to $20 \mu \mathrm{m}$ before constant oxygen concentrations were achieved. The diffusive oxygen flux across the sediment-air interface was calcu- 
lated from Fick's first law according to Revsbech et al. (1986). The oxygen flux from the roots under steadystate conditions in light and darkness was calculated from the cylindrical version of Fick's first law according to Pedersen et al. (1998).

The concentration of dissolved hydrogen sulfide was measured by a Clark-type microelectrode (Unisense, Denmark) developed according to the principle by Jeroschewski et al. (1996). The microelectrode, with a tip diameter $<50 \mu \mathrm{M}$, a $90 \%$ response $<10 \mathrm{~s}$ and stirring sensitivity $<2 \%$, had a detection limit of $<1 \mu \mathrm{M}$. The electrode tip was constructed to be extraordinarily long, which allowed measurements down to $6 \mathrm{~cm}$ sediment depth.

Sulfate reduction rates and pools of reduced sulfides. Sulfate reduction rates were determined by a modification of the core-injection technique (Jørgensen 1978). Three replicate microcosms from each treatment were injected vertically with $150 \mu \mathrm{l}$ of ${ }^{35} \mathrm{~S}$-sulfate $\left(2100 \mathrm{kBq}\right.$ microcosm $\left.{ }^{-1}\right)$. The microcosms were then incubated in darkness for $1 \mathrm{~h}$. The incubation was terminated by sectioning the microcosms into $1 \mathrm{~cm}$ intervals in the upper 4 and $2 \mathrm{~cm}$ intervals down to $10 \mathrm{~cm}$. Half of the sediment was fixed in $1 \mathrm{M}$ zinc acetate (v/v) and stored frozen until distillation according to the 1-step procedure of Fossing \& Jørgensen (1989), while the other half was used for determination of root and rhizome biomass (see below). Pools of total reducible sulfides (TRS) in the distillation traps were determined by the method of Cline (1969).

Porewater and sediment particulate analysis. The 2 remaining microcosms were sectioned to obtain porewater sulfate, sediment characteristics, and root and rhizome biomass. The sediment was sectioned as described above, and half of it was processed for determination of root and rhizome biomass (see below). Porewater was obtained from the other half by centrifugation in double centrifuging tubes (1500 rpm, $10 \mathrm{~min}$ ). Porewater samples were analyzed for sulfate by ionchromatography on a Dionex autosuppressed anion system with carbonate/ bicarbonate as eluent. Water content of the sediment was determined as weight loss after drying for $24 \mathrm{~h}$ at $105^{\circ} \mathrm{C}$. Density was measured as the wet weight of a known volume.

Growth and biomass measurements. The leaf elongation rate was measured once a week by measuring the length of all the leaves in each microcosm. At the end the leaves were cut and freeze dried to obtain dry weight. The depth distribution of roots and rhizomes was obtained by sectioning the sediment as described above. The sediment was gently sieved (1 $\mathrm{mm}$ mesh) and the living roots and rhizomes were collected. The diameter of 10 roots from each microcosm was measured to obtain an estimate of the average root diameter. The biomass was obtained after freeze drying.

\section{RESULTS}

\section{Spartina anglica growth and production}

Leaf growth was fast during the first $70 \mathrm{~d}$ of the experiment, but ceased thereafter (data not shown). The growth may have been restricted by limitations of the experimental design, e.g. the size of microcosms or nutrient availability. Leaves of Spartina anglica appeared to reach larger biomass and higher rates of elongation in the drained microcosms, but due to heterogeneity among microcosms the differences were not significant (paired $t$-test, $\mathrm{p}>0.17$; Table 1 ). The root and rhizome biomass was not significantly different between treatments (paired $t$-test, $\mathrm{p}=0.39$; Table 1 ). The distribution of roots in the surface layers was similar between treatments attaining a maximum (38 to $42 \mathrm{~g} \mathrm{DW} \mathrm{m}^{-2}$ ) in the 0 to $1 \mathrm{~cm}$ depth interval and a minimum (21 to $26 \mathrm{~g} \mathrm{DW}$ $\mathrm{m}^{-2}$ ) in the layer below (Fig. 1). The root biomass increased below this depth in the waterlogged microcosms (up to $60 \%$ ) at deeper depths, whereas no change was observed in the drained microcosms. The root diameter was averaged for all microcosms and found to be $0.95 \pm 0.11 \mathrm{~mm}(\mathrm{n}=100)$.

\section{Oxygen and sulfide in the rhizosphere}

Oxygen was present around the roots of Spartina anglica during both light and dark incubations in a zone of up to $2.5 \mathrm{~mm}$ from the root surfaces (Fig. 2A).

Table 1. Plant data and sulfur cycling in the microcosms under drained and waterlogged conditions. Plant growth is presented as leaf elongation $(n=5 \pm \mathrm{SEM})$. The leaves and roots and rhizome biomass is given as mean of 5 replicates $( \pm$ SEM). The depth integrated rates of sulfate reduction and pools of reduced sulfides are given as mean of 3 replicates $( \pm$ SEM). The effect of waterlogging was tested by a paired $t$-test on all parameters $(\mathrm{p})$, but none were significantly different $(p>0.05)$

\begin{tabular}{|lccc|}
\hline Measurement & Drained & Waterlogged & $\mathrm{p}$ \\
\hline Plant growth $\left(\mathrm{cm} \mathrm{shoot}^{-1}\right)$ & $78.6 \pm 10.1$ & $56.8 \pm 9.7$ & 0.17 \\
$\begin{array}{l}\text { Leaves biomass }\left(\mathrm{g} \mathrm{DW} \mathrm{m} \mathrm{m}^{-2}\right) \\
\text { Root and rhizome biomass }\left(\mathrm{g} \mathrm{DW} \mathrm{m}^{-2}\right)\end{array}$ & $203.1 \pm 55.8$ & $272.1 \pm 70.7$ & 0.55 \\
$\begin{array}{l}\text { Depth-integrated sulfate reduction } \\
\text { rate }\left(\mathrm{mmol} \mathrm{S} \mathrm{m}^{-2} \mathrm{~d}^{-1}\right)\end{array}$ & $5.34 \pm 1.70$ & $4.10 \pm 1.24$ & 0.51 \\
$\begin{array}{l}\text { Depth-integrated pool of reduced } \\
\text { sulfides }\left(\mathrm{mol} \mathrm{S} \mathrm{m}^{-2}\right)\end{array}$ & $12.1 \pm 0.9$ & $14.9 \pm 2.8$ & 0.41 \\
\hline
\end{tabular}




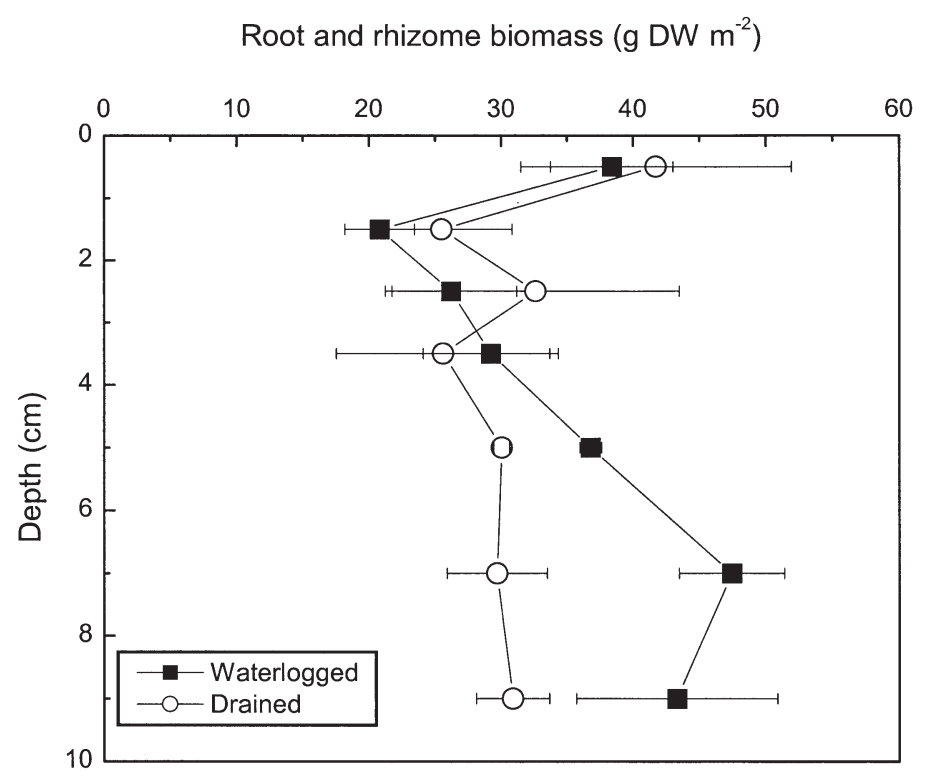

Fig. 1. Depth dependent changes in living root and rhizome biomass $\left(\mathrm{g} \mathrm{DW} \mathrm{m}^{-2}\right.$ ) in response to drained and waterlogged conditions after 4 mo of growth. Each symbol represents the mean of 5 replicates $( \pm$ SEM)

The oxygen concentration and penetration depth in the rhizosphere appeared to be controlled by the diameter of the root; small roots $(\mathrm{d}<0.5 \mathrm{~mm})$ supported lower oxygen levels than larger roots $(\mathrm{d}>0.5 \mathrm{~mm})$. The oxygen concentration around roots was higher during light than dark incubations (Fig. 2B). The oxygen concentration within 2 similarly sized roots $(0.99$ and $0.90 \mathrm{~mm})$ was much higher in the light $(270 \mu \mathrm{M})$ than in dark

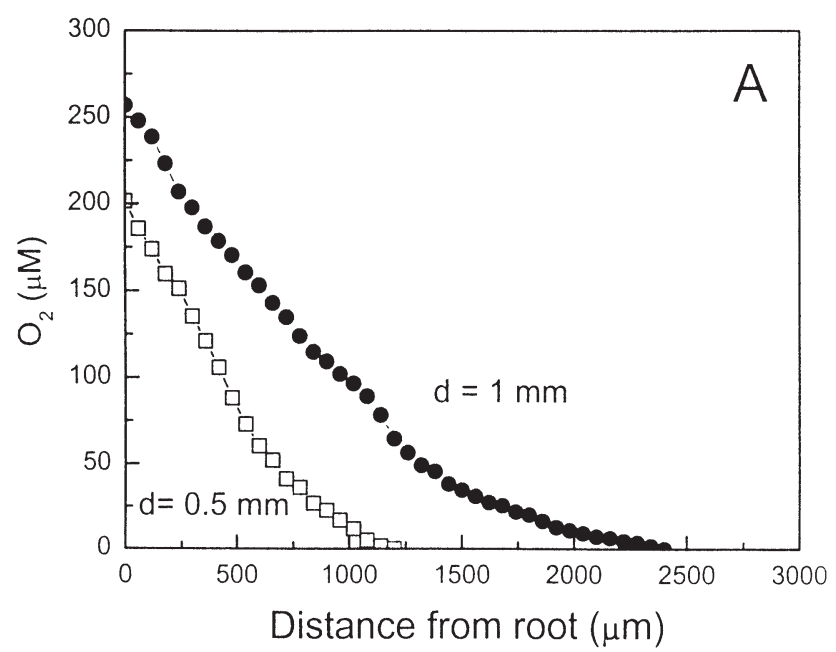

$(55 \mu \mathrm{M})$. As these roots were situated close to the sediment surface $(<3.5 \mathrm{~mm}$ depth) oxygen was present at all depths. In the light oxygen did not decrease below $110 \mu \mathrm{M}$ at any depth within the upper $3.5 \mathrm{~mm}$ and reached almost air-saturation at the root surface. The root measured in the dark was positioned deeper in the sediment, and oxygen declined to $15 \mu \mathrm{M}$ at $2.0 \mathrm{~mm}$ depth and only reached about $20 \%$ of air-saturation towards the root.

We were not able to detect dissolved sulfides in any of the microcosms to the measuring depth of $6 \mathrm{~cm}$, indicating that the sulfide concentration was $<1 \mu \mathrm{M}$ after the 4 mo growth period. The oxygen penetration depth across the sediment-water interface was low (2.2 to $2.5 \mathrm{~mm}$ ), and there was no significant effect of waterlogging $(p=0.24)$ (Fig. 3). Only results from the emerged conditions in dark are presented, as no significant differences were found under submerged and light conditions.

\section{Sulfate reduction rates and total pools of reduced sulfides}

Depth integrated rates of sulfate reduction were not significant different between treatments (paired $t$-test, $\mathrm{p}=0.51$; Table 1). The rates were $5.34 \pm 1.70$ and $4.10 \pm$ $1.24 \mathrm{mmol} \mathrm{m} \mathrm{m}^{-2} \mathrm{~d}^{-1}$ in the drained and waterlogged microcosms, respectively. The depth pattern of sulfate reduction rates showed large heterogeneity especially near the surface sediments of the drained microcosms (Fig. 4). Rates were somewhat higher in the upper $5 \mathrm{~cm}$ of the drained (up to $82 \mathrm{nmol} \mathrm{cm}^{-3} \mathrm{~d}^{-1}$ ) compared with

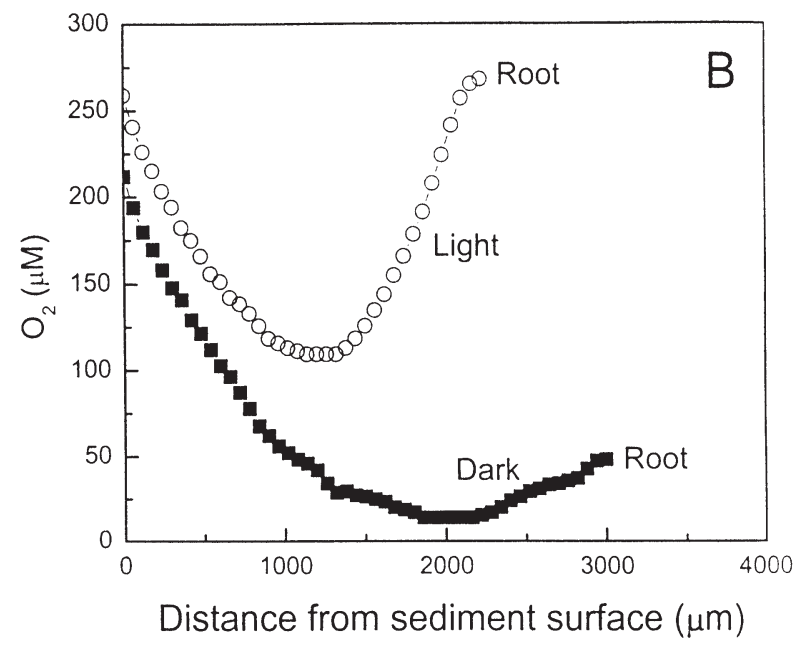

Fig. 2. Measured oxygen concentrations $(\mu \mathrm{M})$ around Spartina anglica roots under various abiotic conditions. (A) Oxygen concentrations measured around roots with a diameter of 0.5 and $1.0 \mathrm{~mm}$, respectively, during emerged conditions in the light in a drained microcosm. (B) Oxygen concentrations measured in a waterlogged microcosm in dark and light incubations. The position of the root from the sediment surface is indicated. Symbols represent single measurements 


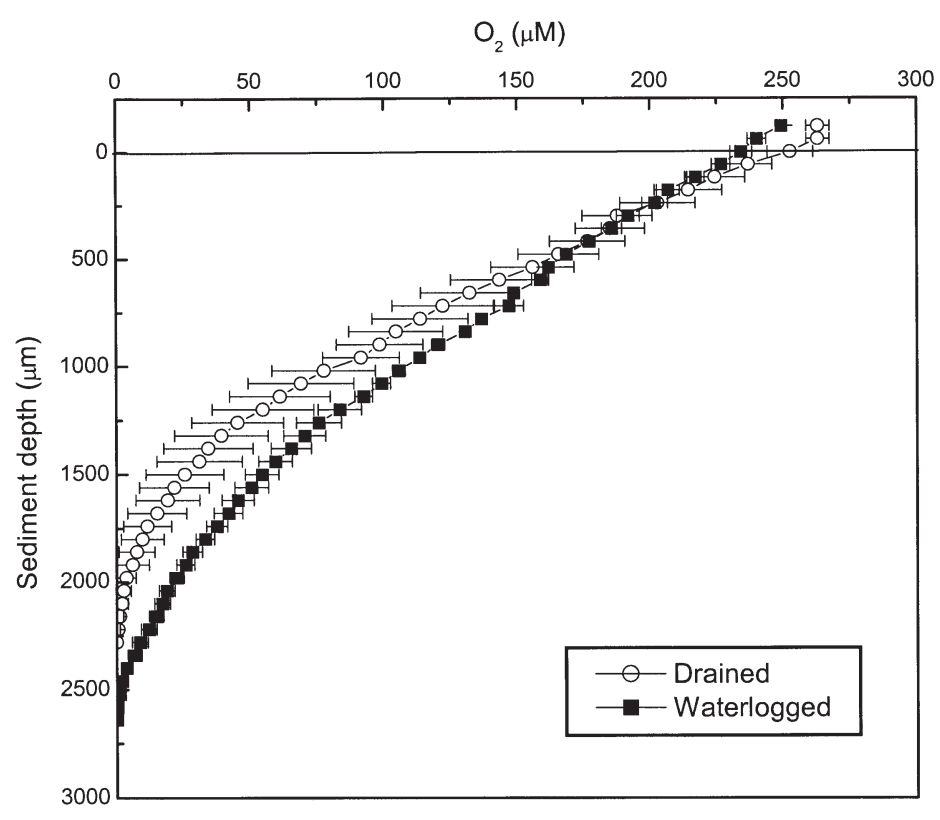

Fig. 3. Oxygen concentrations $(\mu \mathrm{M})$ measured in the dark during emerged conditions in response to drained and waterlogged conditions. Microcosms were kept emerged for $>1 \mathrm{~h}$ before measurements were initiated. Each symbol represent the mean of 3 replicates $( \pm$ SEM)

the waterlogged microcosms (26 to $47 \mathrm{nmol} \mathrm{cm}^{-3} \mathrm{~d}^{-1}$ ), which attained maximum rates in the deeper layers $\left(64 \mathrm{nmol} \mathrm{cm}^{-3} \mathrm{~d}^{-1}\right)$.

The total pools of reduced sulfides were high (12.1 to $14.9 \mathrm{~mol} \mathrm{~S} \mathrm{~m}^{-2}$ ), but not significantly different between treatments (paired $t$-test, $\mathrm{p}=0.41$; Table 1 ). There was a trend for sulfide pools to increase in the waterlogged microcosms compared with the initial sediments, whereas the pools were similar or lower at all depths in the drained microcosms (Fig. 4).

\section{DISCUSSION}

Several studies on salt marsh plants have suggested that there is a root-mediated oxygen supply to the rhizosphere, but it has not yet been measured directly due to methodological difficulties. Our results show for the first time that oxygen actually is present in the rhizosphere of Spartina anglica roots. The oxygen concentration was high in the near-root rhizosphere, and approached air-saturation at the root surface in the light. However, due to the high oxygen consumption by the sediment, oxygen was depleted within a $2.5 \mathrm{~mm}$ radial zone around the root surfaces. The penetration distance of oxygen into the rhizosphere was similar to the oxygen penetration depth across the sedimentwater/air interface despite the radial diffusion geometry, suggesting that the oxygen translocation across
$S$. anglica root surfaces is rapid. Root-mediated oxygen supply to the rhizosphere has also been measured in seagrass beds (Caffrey \& Kemp 1991, Pedersen et al. 1998), in mangrove sediments (Andersen \& Kristensen 1988), in vegetated fresh water sediments (Christensen et al. 1994, Pedersen et al. 1995) and for Potamogeton pectinatus (Caffrey \& Kemp 1991). The oxic rhizosphere is significantly higher around roots of $S$. anglica compared to seagrasses (Pedersen et al. 1998), but similar to P. pectinatus (Caffrey \& Kemp 1991) and less when compared to the freshwater macrophytes Littorella sp. and Lobelia dortmanna (Christensen et al. 1994, Pedersen et al. 1995).

Our understanding of oxygen dynamics in rhizospheres is still limited, and there are several aspects that need further investigation. The present results suggest that the oxygen concentration inside the root varies dependent on the root diameter and surface illumination. Similar patterns have been observed in seagrass sediments (Pedersen et al. 1998). Oxygen was always present in the rhizosphere of the roots, but it was not possible to clarify differences in oxygen concentrations between drained and waterlogged treatments. This suggests that root-mediated oxygen supply was not affected by inundation frequency and sediment drainage. Since the physical limitation of the microelectrodes prevented measurements below $4 \mathrm{~cm}$ depth, we cannot exclude that deeper sediment layers may be affected by the degree of drainage. The depth distribution of the roots was similar within the upper $4 \mathrm{~cm}$, but below this depth the root biomass was highest in the waterlogged sediment. This suggests that Spartina anglica adapt to waterlogging by maintaining a high capacity to oxidize the subsurface sediment. Other studies have shown that Spartina generally is affected negatively by increased waterlogging resorting in reduced root growth and lower rates of photosynthesis (Pezeshki 1997, Portnoy \& Valiela 1997). However, for some Spartina species the effects of waterlogging are only temporary and the plants recover after an acclimatization period (Pezeshki \& DeLaune 1996). The lacunae allocation does not change in $S$. alterniflora with waterlogging, and there are no changes in the internal oxygen transport in the plants (Arenovski \& Howes 1992). This suggests that $S$. anglica have the capacity to oxidize reduced sediments generated during waterlogging.

\section{Oxygen release and oxidation of the sediment}

Sediment oxidation by root-mediated oxygen supply is probably quite significant due to the large root biomass in salt marsh sediments (Howes et al. 1985, Blum 1993). In our microcosms the biomass production is 


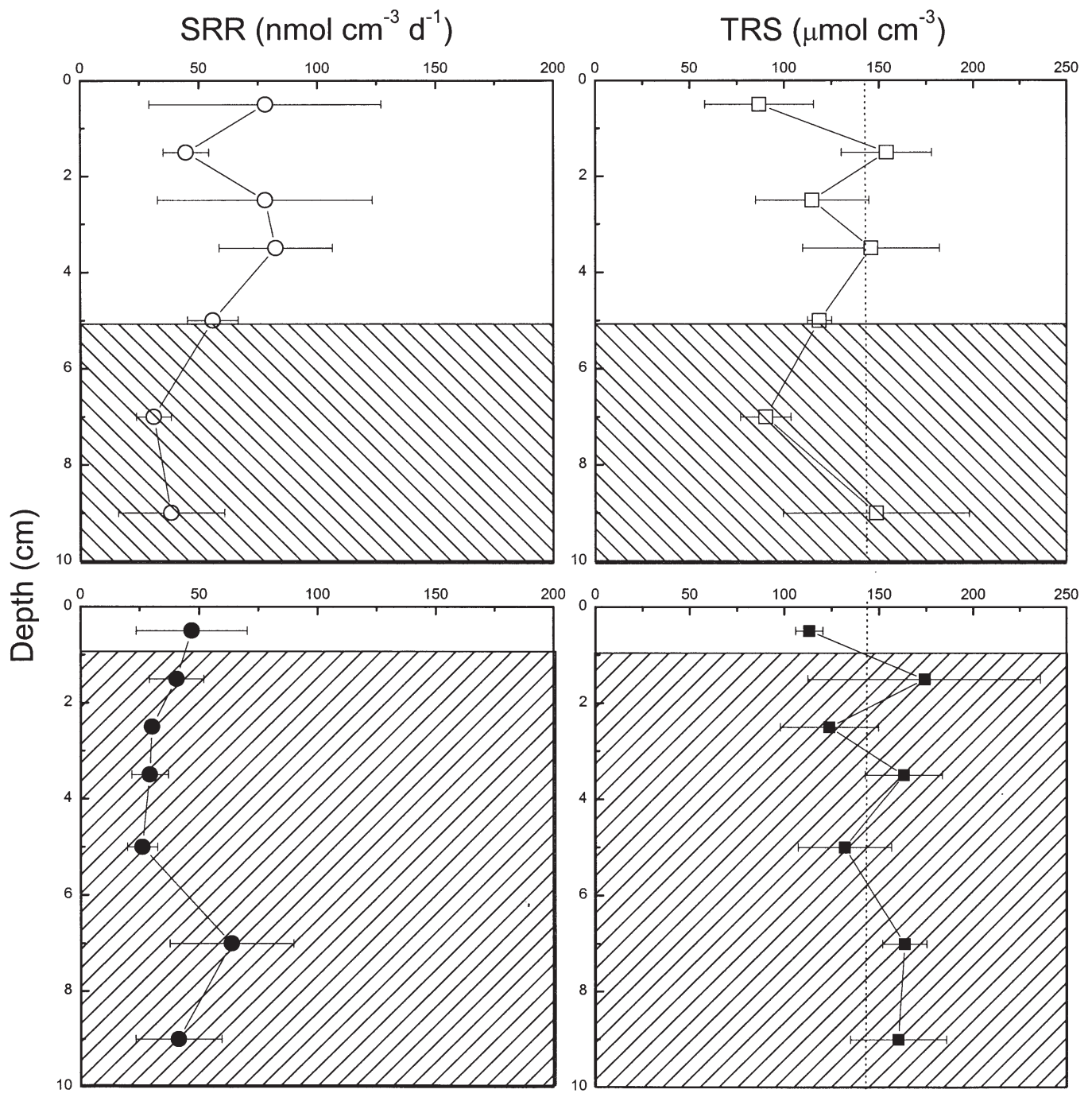

Fig. 4. Depth dependent changes in sulfate reduction rates (SRR, left) and total pools of reduced sulfides (TRS, right) in response to drained (upper) and waterlogged (lower) conditions. Rates and pools were obtained from 3 replicate microcosms $( \pm$ SEM) after 4 mo of growth. Initial TRS concentration is indicated by dotted line and hatched area represents waterlogged part of the sediments

comparable to results obtained in salt marshes during maximum growth in spring (Howes et al. 1985). From the depth distribution and biomass of roots it is estimated that roots comprise approximately $10 \%$ of the total sediment volume in the microcosms. With an average root diameter of $0.95 \mathrm{~mm}$ and an oxic zone of 1 to $2.5 \mathrm{~mm}$ around the roots, 30 to $60 \%$ of the sediment should be oxic. This estimate is considerable higher than the $0.5 \%$ found for seagrasses (Pedersen et al. 1998), but less than for freshwater macrophytes, e.g. Littorella sp., which is capable of maintaining the entire sediment oxic (Christensen et al. 1994). Based on an average root diameter of $0.95 \mathrm{~mm}$, the root area is estimated to be $0.5 \mathrm{~m}^{2} \mathrm{~m}^{-2}$ sediment. The rootmediated flux of oxygen is then calculated to range between 1.5 and $3.7 \mathrm{mmol} \mathrm{m} \mathrm{m}^{-2} \mathrm{~d}^{-1}$ based on the observed oxygen gradients at the root surface. This root- mediated oxygen flux is equivalent to $10-50 \%$ of the diffusive oxygen uptake across the sediment-water/air surface. The root-mediated oxygen supply therefore plays an important role for the total oxygen budget in salt marsh sediments. These calculations may, however, be underestimated because root area may be significantly underestimated, as root hairs were not considered. Nevertheless, the root-mediated flux for Spartina anglica is higher compared to seagrass roots, which contribute relatively little $(<10 \%)$ to the overall sediment oxygen uptake (Pedersen et al. 1998).

\section{Sulfide production and sulfur pools}

The low sulfate reduction rates in the microcosms were most likely caused by inhibition due to the oxida- 
tion capacity of the roots, which also counteracted the effect of waterlogging on the sulfate reduction rates. A major part of the organic matter degradation, therefore, must be mediated by aerobic processes and/or iron and manganese reduction. However, the oxygen may instead be utilized for reoxidation of reduced iron and manganese, as well as sulfide. Oxidized forms of these elements act as electron acceptors and can be used in microbial respiration. High Fe(III) concentrations have been found in these sediments (Boje 2000), and high rates of iron-reduction have been measured in salt marsh sediments (Kostka \& Luther 1995). No dissolved sulfides were detected in the rhizosphere or in the surrounding sediments, suggesting that sulfides were reoxidized rapidly or precipitated as iron-sulfides or elemental sulfur. The root-mediated oxygen supply was sufficient to oxidize 14 to $45 \%$ of the produced sulfide (assuming a 1:2 stochiometry between sulfides produced and oxygen consumed). Although the released oxygen was not sufficient to oxidize all sulfide produced, it is unlikely that roots were exposed directly to sulfide, as the rhizospheres around the roots remained oxic both in the light and dark. The remaining sulfide must have precipitated as iron sulfides in the anoxic zone. Salt marsh sediments contain more iron sulfides mostly in the form of pyrite than most other marine environments (Howarth \& Teal 1979, Gribsholt 2001).

\section{Effect of waterlogging on salt marshes}

There was no effect of waterlogging on oxygen penetration depth or sulfate reduction rates in the Spartina anglica microcosms. There was a trend for lower $S$. anglica growth in the waterlogged sediments. The results suggest that direct effects of sea level rise are not likely to be detrimental for $S$. anglica, as the changes in sediment biogeochemical conditions are compensated by a root-mediated supply of oxygen into the rhizosphere. Other plants species with less developed root systems and lower oxygen translocation capacity are more likely to be affected by waterlogging. If sea level rise affects these species negatively, it will impose a change in the composition of plant communities favoring oxygen translocating species as Spartina sp.

It is, however, not possible to exclude direct and indirect effects of sea level rise on Spartina anglica under in situ conditions. The sulfate reduction rates measured in our microcosms are similar to the low rates observed in a dry Spartina marsh at Waarde in the Westerschelde Estuary, The Netherlands; however, much higher rates have been measured in the more waterlogged marsh close to the seaward edge (Gribs- holt 2001). These plants may be susceptible to even small changes in redox conditions during a sea level rise. This seaward edge of the marsh is fragile because of high erosion if plants disappear.

Acknowledgements. This research was funded by the Commission of the European Communities (ENV4-CT97-0582) and grant no. 9901749 from the Danish National Research Foundation. We thank Susanne Boerits for technical assistance and Ole Pedersen for measurement of sulfide profiles and for comments on this manuscript.

\section{LITERATURE CITED}

Adam P (1990) Saltmarsh ecology. The University Press, Cambridge

Andersen FØ, Kristensen E (1988) Oxygen microgradients in the rhizosphere of the mangrove Avicennia marina. Mar Ecol Prog Ser 44:201-204

Arenovski AL, Howes BL (1992) Lacunal allocation and gas transport capacity in the salt marsh grass Spartina alterniflora. Oecologia 90:316-322

Armstrong J, Afreen-Zobayed F, Armstrong W (1996) Phragmites die-back: sulphide- and acetic acid-induced bud and root death, lignifications, and blockages within aeration and vascular systems. New Phytol 134:601-614

Blum LK (1993) Spartina alterniflora root dynamics in a Virginia marsh. Mar Ecol Prog Ser 102:169-178

Boje J (2000) The effect of Spartina anglica on sulfate reduction and sulfur cycling in the Wadden Sea. MSc thesis, Odense University (in Danish)

Boorman LA (1999) Salt marshes-present functioning and future change. Mangroves Salt Marshes 3:227-241

Caffrey JM, Kemp WM (1991) Seasonal and spatial patterns of oxygen production, respiration and root-rhizome release in Potamogeton perfoliatus L. and Zostera marina L. Aquat Bot 40:109-128

Christensen PB, Revsbech NP, Sand-Jensen K (1994) Microsensor analysis of oxygen in the rhizosphere of the aquatic macrophytes Littorella uniflora (L.) Ascherson. Plant Physiol 105:847-852

Cline JD (1969) Spectrophotometric determination of hydrogen sulfide in natural waters. Limnol Oceanogr 14: $454-458$

Fossing H, Jørgensen BB (1989) Measurement of bacterial sulfate reduction in sediments: evaulation of a single-step chromium reduction method. Biogeochemistry 8:205-222

Fürtig K, Rüegsegger A, Brunold C, Brändle R (1996) Sulphide utilization and injuries in hypoxic roots and rhizomes of common reed (Phragmites australis). Folia Geobot Phytotaxon 31:143-151

Gleason ML, Zieman JC (1981) Influence of tidal inundation on internal oxygen supply of Spartina alterniflora and Spartina patens. Estuar Coast Shelf Sci 13:47-57

Gribsholt B (2001) The influence of macrophytes and benthic infauna on rates and pathways of carbon mineralization in salt marsh sediments. $\mathrm{PhD}$ thesis, Odense, University

Howarth RW, Teal JM (1979) Sulfate reduction in a New England saltmarsh. Limnol Oceanogr 24:999-1013

Howes BL, Teal JM (1994) Oxygen loss from Spartina alterniflora and its relationship to salt marsh oxygen balance. Oecologia 97:431-438

Howes BL, Dacey JWH, Teal JM (1985) Annual carbon mineralization and belowground production of Spartina alterniflora in a New England salt marsh. Ecology 66:595-605 
Jeroschewski P, Steuckart C, Kühl M (1996) An amperometric microsensor for the determination of $\mathrm{H}_{2} \mathrm{~S}$ in aquatic environments. Anal Chem 68:4351-4357

Jørgensen BB (1978) A comparison of methods for the quantification of bacterial sulfate reduction in coastal marine sediments. Geomicrob J 1:11-27

Koch MS, Mendelssohn IA, McKee KL (1990) Mechanism for the hydrogen sulfide-induced growth limitation in wetland macrophytes. Limnol Oceanogr 35:399-408

Kostka JE, Luther GW III (1995) Seasonal cycling of Fe in saltmarsh sediments. Biogeochemistry 29:159-181

Mendelssohn IA, McKee KL (1988) Spartina alterniflora dieback in Louisiana: time-course investigation of soil waterlogging effects. J Ecol 76:509-521

Mendelssohn IA, Patrick WH (1981) Oxygen deficiency in Spartina alterniflora roots: metabolic adaptation to anoxia. Science 214:439-441

Naidoo G, McKee KL, Mendelssohn IA (1992) Anatomical and metabolic responses to waterlogging and salinity in Spartina alterniflora and S. patens (Poaceae). Am J Bot 79: $765-770$

Pedersen O, Sand-Jensen K, Revsbech NP (1995) Diel pulses

Editorial responsibility: Otto Kinne (Editor),

Oldendorf/Luhe, Germany of $\mathrm{O}_{2}$ and $\mathrm{CO}_{2}$ in sandy lake sediments inhabited by Lobelia dortmanna. Ecology 76:1536-1545

Pedersen O, Borum J, Duarte CM, Fortes MD (1998) Oxygen dynamics in the rhizosphere of Cymodocea rotundata. Mar Ecol Prog Ser 169:283-288

Pezeshki SR (1997) Photosynthesis and root growth in Spartina alterniflora in relation to root zone aeration. Photosynthetica 34:107-114

Pezeshki SR, DeLaune RD (1990) Influence of sediment oxidation-reduction potential on root elongation in Spartina patens. Acta Oecol 11:377-383

Pezeshki SR, DeLaune RD (1996) Responses of Spartina alterniflora and Spartina patens to rhizosphere oxygen defiency. Acta Oecol 17:365-378

Portnoy JW, Valiela I (1997) Short-term effects of salinity reduction and drainage on salt-marsh biogeochemical cycling and Spartina (cordgrass) production. Estuaries 20: $569-578$

Revsbech NP, Madsen B, Jørgensen BB (1986) Oxygen production and consumption in sediments determined at high spatial resolution by computer simulation of oxygen microelectrode data. Limnol Oceanogr 31:293-304

Submitted: March 19, 2001, Accepted: June 21, 2001

Proofs received from author(s): January 8, 2002 